[Chem. Pharm. Bull.

32(10)3906-3911(1984) $]$

\title{
Studies on the Constituents of Medicinal and Related Plants in Sri Lanka. I. New Triterpenes from Hedyotis lawsoniae
}

\author{
Tohru Kikuchi, ${ }^{*}$ Satoko Matsuda, Shigetoshi Kadota, \\ Yoshiko Sakai, Tsuneo Namba, Kazuo Watanabe, and \\ Dissanayake Mudiyanselage Ran Banda Dissanayake \\ Research Institute for Wakan-Yaku (Oriental Medicines), \\ Toyama Medical and Pharmaceutical University, \\ 2630 Sugitani, Toyama 930-01, Japan
}

(Received February 18, 1984)

\begin{abstract}
Three new triterpene acids were isolated from the twigs and leaves of Hedyotis lawsoniae, together with sixteen known ones. The new compounds were determined to be $3 \beta, 23$-dihydroxyurs12-en-28-oic acid, 3 $\beta, 24$-dihydroxyurs-12-en-28-oic acid, and 2 $\alpha, 3 \beta, 24$-trihydroxyurs-12-en-28-oic acid on the basis of spectroscopic evidence.
\end{abstract}

Keywords-Hedyotis lawsoniae; Rubiaceae; triterpene; 3 $\beta, 23$-dihydroxyurs-12-en-28-oic acid; $3 \beta, 24$-dihydroxyurs-12-en-28-oic acid; $2 \alpha, 3 \beta, 24$-trihydroxyurs-12-en-28-oic acid

Some of the Hedyotis plants (Rubiaceae) are used as folk medicines in India and Sri Lanka. For instance, $H$. auricularia L. was used for the treatment of diarrhea and dysentery in India, while it is taken as a vegetable effective to reduce high blood pressure in Sri Lanka. ${ }^{1)}$ In the course of our studies on the biologically active constituents of medicinal plants and related plants in Sri Lanka, we obtained three new triterpenes from Hedyotis lawsoniae (DC.) WIGHT et ARN., along with sixteen known ones. This paper describes the structure assignments of these triterpenes.

The methanolic extract of dried twigs and leaves of Hedyotis lawsoniae was separated into the ethyl acetate-soluble part and the water-soluble one. The former was roughly separated by silica gel column chromatography, and the fractions were further separated by preparative layer chromatography (PLC), or high-performance liquid chromatography (HPLC), giving new triterpenes (1a-3a) along with known ones (4a-19a) (see Experimental). Among these, ursolic acid (4a), 3-epiursolic acid (5a) ${ }^{2)}$ ursonic acid (6a), asiatic acid (8a), ${ }^{3)}$ euscaphic acid (12a) ${ }^{4)}$ oleanolic acid (13a), oleanonic acid (14a), sumaresinolic acid (15a), ${ }^{5)}$ hederagenin (16a), arjunolic acid $(\mathbf{1 7 a}),{ }^{3)}$ betulinic acid (18a), and betulin (19a) were identified by direct comparisons of the proton nuclear magnetic resonance $\left({ }^{1} \mathrm{H}-\mathrm{NMR}\right)$ spectra, gas chromatographic (GC) retention times, and gas chromatography-mass spectrometry (GC-MS) data with those of corresponding authentic samples. On the other hand, identification of $2 \alpha$-hydroxyursolic acid (7a), $\left.{ }^{6}\right) 2 \alpha$-hydroxy-3epiursolic acid (9a), ${ }^{7)} 2 \alpha, 3 \alpha, 23$-trihydroxyurs-12-en-28-oic acid (10a), ${ }^{8)}$ and benthamic acid $\left(\right.$ (11a) $^{9)}$ was performed by comparisons of the MS and ${ }^{1} \mathrm{H}-\mathrm{NMR}$ spectra with those described in the literature.

Compounds 1a and $2 \mathbf{a}$ were isolated as the methyl ester diacetates: $1 \mathbf{b}, \mathrm{mp} 180-181.5^{\circ} \mathrm{C}$, $\mathrm{C}_{35} \mathrm{H}_{54} \mathrm{O}_{6},[\alpha]_{\mathrm{D}}+64.1^{\circ}\left(\mathrm{CHCl}_{3}\right)$, and $2 \mathrm{~b}, \mathrm{mp} 180-182^{\circ} \mathrm{C}, \mathrm{C}_{35} \mathrm{H}_{54} \mathrm{O}_{6},[\alpha]_{\mathrm{D}}+50.8^{\circ}\left(\mathrm{CHCl}_{3}\right)$, after methylation and acetylation. The purification of $\mathbf{1 b}$ was difficult, but it was achieved by preparative HPLC.

In the MS, both compounds showed the base peak at $m / z 262$, ascribable to the 

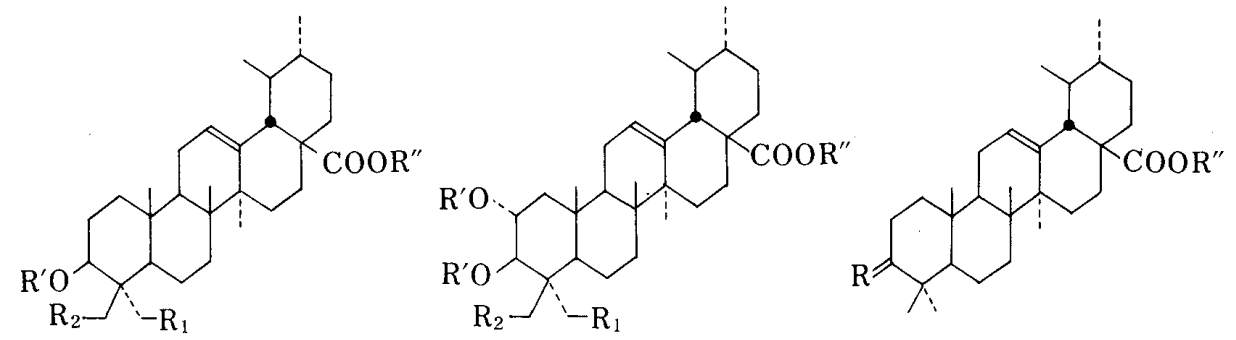

$1: \mathrm{R}_{1}=\mathrm{OR}^{\prime}, \mathrm{R}_{2}=\mathrm{H}$
$2: \mathrm{R}_{1}=\mathrm{H}, \mathrm{R}_{2}=\mathrm{OR}^{\prime}$
$4: \mathrm{R}_{1}=\mathrm{R}_{2}=\mathrm{H}$

$3: \mathrm{R}_{1}=\mathrm{H}, \mathrm{R}_{2}=\mathrm{OR}^{\prime}$

$7: \mathrm{R}_{1}=\mathrm{R}_{2}=\mathrm{H}$

$8: \mathrm{R}_{1}=\mathrm{OR}^{\prime}, \mathrm{R}_{2}=\mathrm{H}$

$5: \mathbf{R}=\alpha-\mathrm{OR}^{\prime}, \beta-\mathrm{H}$

6: $\mathrm{R}=\mathrm{O}$

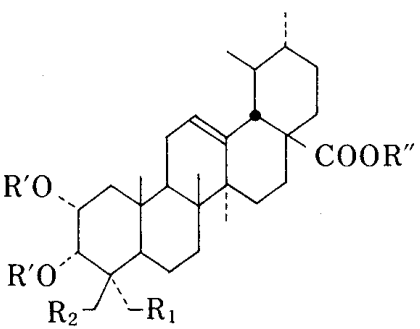

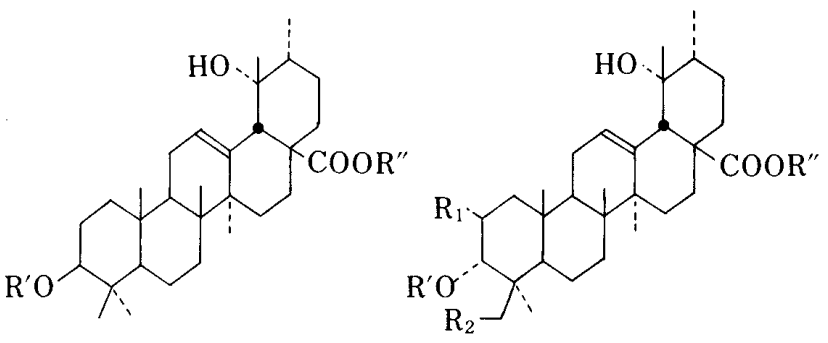

9: $\mathrm{R}_{1}=\mathrm{R}_{2}=\mathrm{H}$

10: $\mathrm{R}_{1}=\mathrm{OR}^{\prime}, \mathrm{R}_{2}=\mathrm{H}$

$20: \mathrm{R}_{1}=\mathrm{H}, \mathrm{R}_{2}=\mathrm{OR}^{\prime}$

11

$12: \mathrm{R}_{1}=\mathrm{OR}^{\prime}, \mathrm{R}_{2}=\mathrm{H}$

21: $\mathrm{R}_{1}=\mathrm{H}, \mathrm{R}_{2}=\mathrm{OR}^{\prime}$

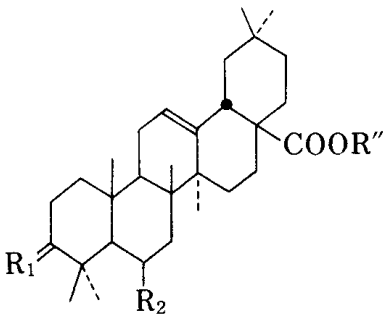

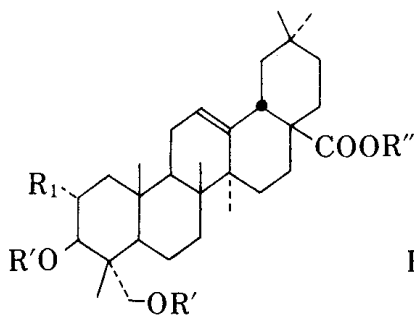<smiles>[R]OC1CCC2(C)C3CCC4C5C(C(=C)C)CCC5([R])CCC4(C)C3CCC2C1(C)C</smiles>

$13: \mathrm{R}_{1}=\alpha-\mathrm{H}, \beta-\mathrm{OR}^{\prime}, \mathrm{R}_{2}=\mathrm{H}$
$14: \mathrm{R}_{1}=\mathrm{O}, \mathrm{R}_{2}=\mathrm{H}$

$16: \mathrm{R}=\mathrm{H}$

$17: \mathrm{R}=\mathrm{OR}^{\prime}$

$18: \mathrm{R}=\mathrm{COOR}^{\prime \prime}$

$15: \mathrm{R}_{1}=\alpha-\mathrm{H}, \beta-\mathrm{OR}^{\prime}, \mathrm{R}_{2}=\mathrm{OH}$

$a: R^{\prime}=R^{\prime \prime}=H, b: R^{\prime}=A c, R^{\prime \prime}=M e$

Chart 1

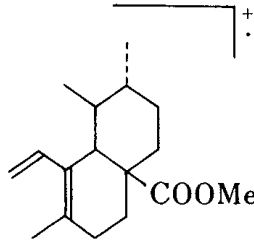

a $: m / z 262$

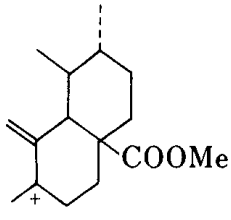

b : $m / z 249$<smiles>C=CC1=C(C)CCC2CCC(C)C(C)C12</smiles>

c $: m / z 203$<smiles>[C+]C1=CC(C=C)=C(C)CC1</smiles>

$\mathrm{d}: m / z 133$

Chart 2

retro-Diels-Alder fragment ion (a), along with peaks at $m / z 249$ (b), 203 (c), 189 (c-14), and $133(\mathrm{~d})$, which are characteristic of $\Delta^{12}$-oleanene or $\Delta^{12}$-ursene type triterpenes (Chart 2). $\left.{ }^{10}\right)$ The ${ }^{1} \mathbf{H}$-NMR spectra of $\mathbf{1 b}$ and $\mathbf{2 b}$ showed significant signals assignable to the 18-proton at $\delta 2.25(\mathrm{~d}, J=11 \mathrm{~Hz})$ and the 12-olefinic proton at $\delta 5.25(\mathrm{brt}, J=3.5 \mathrm{~Hz})$, together with two 
sec-methyl and four tert-methyl signals, whose signal pattern is suggestive of the structural features of urs-12-en-28-oic acid. ${ }^{11)}$ In view of these data, $\mathbf{1 b}$ and $\mathbf{2 b}$ were presumed to be methyl urs-12-en-28-oate derivatives having two acetoxyl groups. These two acetoxyls may be present at ring $A$ rather than ring $B$, since the acetylation of $\mathbf{1 a}$ and $2 \mathbf{a}$ leading to $\mathbf{1 b}$ and $\mathbf{2 b}$, respectively, proceeded smoothly under very mild conditions. The positions and configuration of these acetoxyls in each compound were determined by ${ }^{1} \mathrm{H}-\mathrm{NMR}$ analyses as described below.

The ${ }^{1} \mathrm{H}-\mathrm{NMR}$ spectrum of $\mathbf{1 b}$ showed signals due to a methine proton at $\delta 4.81(\mathrm{dd}, J=$ $10,5.5 \mathrm{~Hz}, \mathrm{C}$ HOAc) and methylene protons at $\delta 3.71$ and 3.88 (each $1 \mathrm{H}, \mathrm{d}, J=12 \mathrm{~Hz}$, $\mathrm{CH}_{2} \mathrm{OAc}$ ), along with two acetyl methyl signals ( $\delta 2.02$ and 2.07$)$. This spectral pattern closely resembles that of authentic 16b. Thus, the compound was determined to be methyl $3 \beta, 23-$ diacetoxyurs-12-en-28-oate (1b).

On the other hand, compound $\mathbf{2 b}$ showed a ${ }^{1} \mathrm{H}-\mathrm{NMR}$ spectrum very similar to that of $\mathbf{1 b}$, except for signals arising from a $\mathrm{CH}_{2} \mathrm{OAc}$ group and a tert-methyl group. The signals due to the acetoxyl-bearing methylene $(\delta 4.13$ and 4.36 , each $1 \mathrm{H}, \mathrm{d}, J=12 \mathrm{~Hz})$ were shifted downfield relative to the 23-methylene signals of $\mathbf{1 b}$, and these chemical shifts are virtually the same as those of the 24-methylene protons of methyl $2 \alpha, 3 \alpha, 24$-triacetoxyurs-12-en-28-oate $(\mathbf{2 0 b})^{12)}$ and methyl barbinervate diacetate (21b) ${ }^{13)}$ In addition, the methyl group at the C-4 position resonated downfield (ca. $0.08 \mathrm{ppm}$ ) relative to the 23 -methyl signal of $\mathbf{4 b}$. This behavior was also parallel with those of $\mathbf{2 0 b}$ and $\mathbf{2 1 b}$, whose 23-methyl signals appeared downfield relative to those of $\mathbf{9 b}$ and $\mathbf{5 b}$, as shown in Table I. On the other hand, in the case of 23-acetoxylated triterpenes, the signal of the 24-methyl group was reported to appear at about the same region as the corresponding signal of non-substituted compounds. ${ }^{11 a)}$ Therefore, these data indicated that the primary acetoxyl group of $\mathbf{2 b}$ is located at the 24-position. Since the signal due to the 3-proton was observed at $\delta 4.60(\mathrm{dd}, J=9,7 \mathrm{~Hz})$, this compound was established to be methyl 3 $\beta$,24-diacetoxyurs-12-en-28-oate (2b).

Compound 3a was also obtained as the methyl ester triacetate (3b), amorphous powder, $\mathrm{C}_{37} \mathrm{H}_{56} \mathrm{O}_{8},[\alpha]_{\mathrm{D}}+51^{\circ}\left(\mathrm{CHCl}_{3}\right)$. The gross structure of this compound was suggested by the MS base peak at $m / z 262$ (a) and the ${ }^{1} \mathrm{H}$-NMR pattern, which is similar to that of $\mathbf{2 b}$. Furthermore, the ${ }^{1} \mathrm{H}$-NMR spectrum showed signals due to the methine protons geminal to acetoxyl groups at $\delta 4.86(\mathrm{~d}, J=10.5 \mathrm{~Hz})$ and $5.18(\mathrm{td}, J=10.5$ and $4.5 \mathrm{~Hz})$, indicating the presence of a $2 \alpha, 3 \beta$-glycol diacetate system. The signals arising from the methylene protons at $\delta 4.21$ (s) and a methyl group at $\delta 1.02$ (Table I) suggested that the third acetoxyl group should be located at the 24-position. In addition, the $3 \alpha$-proton of $\mathbf{2 b}$ and $\mathbf{3 b}$ resonated downfield by 0.09 and $0.08 \mathrm{ppm}$, respectively, relative to the corresponding proton of $\mathbf{4 b}$ and $7 \mathbf{b}$,

TABLE I. Chemical Shifts of Methyl Signals in Several 24-Acetoxylated Triterpenes ( $\delta$ in $\mathrm{CDCl}_{3}$ )

\begin{tabular}{clccc}
\hline \hline & \multicolumn{4}{c}{ Methyl signals } \\
Compound \\
\cline { 2 - 5 } (Position of AcO group) & 23 & 24 & 25 & 26 \\
\hline $\mathbf{4 b}(3 \beta)$ & 0.87 & 0.88 & 0.94 & 0.74 \\
$\mathbf{2 b}(3 \beta, 24)$ & $0.95^{a)}$ & - & $1.01^{a)}$ & 0.74 \\
$\mathbf{5 b}(3 \alpha)$ & 0.86 & 0.90 & 0.95 & 0.76 \\
$\mathbf{2 1 b}(3 \alpha, 24)$ & $0.95^{a)}$ & - & $0.93^{a)}$ & 0.68 \\
$\mathbf{7 b}(2 \alpha, 3 \beta)$ & 0.90 & 0.90 & 1.05 & 0.74 \\
$\mathbf{3 b}(2 \alpha, 3 \beta, 24)$ & 1.02 & - & 1.06 & 0.73 \\
$\mathbf{9 b}(2 \alpha, 3 \alpha)$ & 0.87 & 0.98 & 1.04 & 0.75 \\
$\mathbf{2 0 b}(2 \alpha, 3 \alpha, 24)$ & 0.98 & - & 1.05 & 0.75 \\
\hline
\end{tabular}

a) Assignments may be interchanged as indicated in each compound. 
Table II. Chemical Shifts of Methine and Methylene Protons of Carbons Carrying Acetoxyl Groups ( $\delta$ in $\mathrm{CDCl}_{3}$ )

\begin{tabular}{|c|c|c|c|}
\hline \multirow{2}{*}{$\begin{array}{l}\text { Compound } \\
\text { (Position of } \\
\mathrm{AcO} \text { group) }\end{array}$} & \multicolumn{3}{|c|}{ Chemical shifts } \\
\hline & $2 \beta-\mathrm{H}$ & $3 \alpha-\mathrm{H}$ & $23-\mathrm{H}_{2}$ or $24-\mathrm{H}_{2}$ \\
\hline $\mathbf{4 b}(3 \beta)$ & - & $\begin{array}{c}4.51 \\
(\mathrm{dd}, J=9,7 \mathrm{~Hz})\end{array}$ & - \\
\hline $\mathbf{1 b}(3 \beta, 23)$ & - & $\begin{array}{c}4.81 \\
(\mathrm{dd}, J=10,5.5 \mathrm{~Hz})\end{array}$ & $\begin{array}{c}3.71,3.88 \\
\text { (each d, } J=12 \mathrm{~Hz})\end{array}$ \\
\hline $\mathbf{2 b}(3 \beta, 24)$ & - & $\begin{array}{c}4.60 \\
(\mathrm{dd}, J=9,7 \mathrm{~Hz})\end{array}$ & $\begin{array}{c}4.13,4.36 \\
(\text { each d, } J=12 \mathrm{~Hz})\end{array}$ \\
\hline $7 \mathbf{b}(2 \alpha, 3 \beta)$ & $\begin{array}{c}5.14 \\
(\mathrm{td}, J=10,4.5 \mathrm{~Hz})\end{array}$ & $\begin{array}{c}4.78 \\
(\mathrm{~d}, J=10 \mathrm{~Hz})\end{array}$ & - \\
\hline $\mathbf{8 b}(2 \alpha, 3 \beta, 23)$ & $(\mathrm{td}, J=10,4.5 \mathrm{~Hz})$ & $\begin{array}{c}5.12 \\
(\mathrm{~d}, J=10 \mathrm{~Hz})\end{array}$ & $\begin{array}{c}3.62,3.89 \\
(\text { each d, } J=12 \mathrm{~Hz})\end{array}$ \\
\hline $\mathbf{3 b}(2 \alpha, 3 \beta, 24)$ & $\begin{array}{c}5.18 \\
(\mathrm{td}, J=10.5,4.5 \mathrm{~Hz})\end{array}$ & $\begin{array}{c}4.86 \\
(\mathrm{~d}, J=10.5 \mathrm{~Hz})\end{array}$ & $\begin{array}{c}4.20 \\
(\mathrm{~s})\end{array}$ \\
\hline
\end{tabular}

whereas that of $\mathbf{1 b}$ and $\mathbf{8 b}$ appeared further downfield by 0.30 and $0.34 \mathrm{ppm}$, respectively, in comparison with that of $\mathbf{4 b}$ and $\mathbf{7 b}$, as shown in Table II. These results supported the trans relationship between the acetoxymethyl group and the $3 \alpha$-proton in $\mathbf{3 b}$. From the above findings, compound $\mathbf{3 b}$ was determined to be $2 \alpha, 3 \beta, 24$-triacetoxyurs-12-en-28-oate (3b).

\section{Experimental}

Melting points were determined with a Kofler-type apparatus and are uncorrected. Optical rotations were measured with a JASCO DIP-4 automatic polarimeter. ${ }^{1} \mathrm{H}-\mathrm{NMR}$ spectra were recorded on a Varian Associates XL200 spectrometer and tetramethylsilane (TMS) in $\mathrm{CDCl}_{3}$ was used as an internal standard. MS and high resolution MS were obtained with a JEOL JMS-D 300 spectrometer. Column chromatography was carried out using Mallinckrodt silica gel and the columns were eluted with $\mathrm{MeOH}-\mathrm{CHCl}_{3}$ mixtures of increasing $\mathrm{MeOH}$ contents, unless otherwise stated. The eluted solutions were concentrated in vacuo. For thin layer chromatography (TLC), Kieselgel $60 \mathrm{~F}_{254}$ (Merck) was used and spots were detected by spraying a $\mathrm{Ce}\left(\mathrm{SO}_{4}\right)_{2}$-aq. $\mathrm{H}_{2} \mathrm{SO}_{4}$ reagent. For PLC, Kieselgel $\mathrm{PF}_{254}$ or $\mathrm{F}_{254}$ (Merck) was employed and the plates were examined after exposure to $\mathbf{I}_{2}$ vapor or under ultraviolet (UV) light. Extraction of substances from the silica gel was done with $\mathrm{MeOH}-\mathrm{CH}_{2} \mathrm{Cl}_{2}$ mixture. The organic solutions were dried over anhydrous $\mathrm{MgSO}_{4}$. Gas chromatography (GC) was done on a GC-6AM instrument (Shimadzu) with a $3 \% \mathrm{SE}-300$ or a $2 \%$ OV-17 column $\left(2 \mathrm{~m} \times 3 \mathrm{~mm}\right.$ i.d. glass tube; injection temp. $300^{\circ} \mathrm{C}$, column temp. $280^{\circ} \mathrm{C}$, carrier gas $\mathrm{N}_{2}$ ).

Isolation of Triterpenes from $\boldsymbol{H}$. lawsoniae - Dried twigs and leaves $(1.69 \mathrm{~kg})$ of $\boldsymbol{H}$. lawsoniae, collected at Horton Plains in Sri Lanka, were extracted with boiling $\mathrm{MeOH}(51 \times 3)$ and the extracts were combined and concentrated in vacuo. The residue was diluted with water $(11)$ and extracted with $\mathrm{AcOEt}(500 \mathrm{ml} \times 3)$. The combined AcOEt extract was washed with water, dried, and concentrated in vacuo to give a syrupy residue $(20 \mathrm{~g})$. This was suspended in $\mathrm{MeOH}-\mathrm{CH}_{2} \mathrm{Cl}_{2}(1: 9)(200 \mathrm{ml})$ and the insoluble material $(\mathrm{F}-\mathrm{I})(4.58 \mathrm{~g})$ was separated by filtration. The filtrate was concentrated in vacuo and the residue $(15 \mathrm{~g})$ was subjected to silica gel $(450 \mathrm{~g})$ column chromatography, giving four fractions containing triterpenes: $v i z$. the $\mathrm{MeOH}-\mathrm{CHCl}_{3}(2: 98)$ eluate (F-II, $2.57 \mathrm{~g}$ ), the earlier part of the $\mathrm{MeOH}-\mathrm{CHCl}_{3}(5: 95)$ eluate (F-III, $\left.1.81 \mathrm{~g}\right)$, the later part of the $\mathrm{MeOH}-\mathrm{CHCl}_{3}(5: 95)$ eluate (F-IV, $1.45 \mathrm{~g}$ ), and the $\mathrm{MeOH}-\mathrm{CHCl}_{3}(1: 9)$ eluate $(\mathrm{F}-\mathrm{V}, 1.12 \mathrm{~g})$.

F-I was rechromatographed on a silica gel $(200 \mathrm{~g})$ column. The eluate with $\mathrm{MeOH}-\mathrm{CHCl}_{3}(1: 99)$ was concentrated to give ursolic acid $(4 a)(1.45 \mathrm{~g})$ as a colorless powder. The subsequent eluate with $\mathrm{MeOH}-\mathrm{CHCl}_{3}$ $(5: 95)(1.27 \mathrm{~g})$ was methylated with $\mathrm{CH}_{2} \mathrm{~N}_{2}$ and subjected to PLC with acetone-CHCl $(5: 95)$ as the eluent. The less polar band gave methyl ursolate $(0.97 \mathrm{~g})$, which was identified by GC, MS, and ${ }^{1} \mathrm{H}-\mathrm{NMR}$ comparisons with an authentic sample. The more polar band afforded the methyl ester of benthamic acid (11a) $(60 \mathrm{mg})$, amorphous powder, $[\alpha]_{\mathrm{D}}^{22}+29.8^{\circ}\left(c=0.55, \mathrm{CHCl}_{3}\right)$. MS $m / z: 486\left(\mathrm{M}^{+}\right), 468,278,260,201,179$. High resolution MS: Found 486.3699, Calcd for $\mathrm{C}_{31} \mathrm{H}_{50} \mathrm{O}_{4}\left(\mathrm{M}^{+}\right)$486.3708. This ester was acetylated with $\mathrm{Ac}_{2} \mathrm{O}$-pyridine and recrystallized from $\mathrm{MeOH}$ to give the monoacetate $(11 \mathrm{~b})(31 \mathrm{mg})$, colorless needles, mp 197-199 ${ }^{\circ} \mathrm{C} .{ }^{1} \mathrm{H}-\mathrm{NMR}\left(\mathrm{CDCl}_{3}\right) \delta: 0.69(3 \mathrm{H}, \mathrm{s}$, 
$\left.26-\mathrm{H}_{3}\right), 0.87\left(3 \mathrm{H}, \mathrm{s}, 23-\mathrm{H}_{3}\right), 0.88\left(3 \mathrm{H}, \mathrm{s}, 24-\mathrm{H}_{3}\right), 0.94\left(3 \mathrm{H}, \mathrm{s}, 25-\mathrm{H}_{3}\right), 0.96\left(3 \mathrm{H}, \mathrm{d}, J=6 \mathrm{~Hz}, 30-\mathrm{H}_{3}\right), 1.23\left(3 \mathrm{H}, \mathrm{s}, 27-\mathrm{H}_{3}\right)$, $1.25\left(3 \mathrm{H}, \mathrm{s}, 29-\mathrm{H}_{3}\right), 2.07(3 \mathrm{H}, \mathrm{s}, \mathrm{OAc}), 2.62(1 \mathrm{H}, \mathrm{s}, 18-\mathrm{H}), 3.63\left(3 \mathrm{H}, \mathrm{s}, \mathrm{COOCH}_{3}\right), 4.54(1 \mathrm{H}, \mathrm{dd}, J=9,7 \mathrm{~Hz}, 3-\mathrm{H})$, and $5.39(1 \mathrm{H}, \mathrm{t}, J=3.5 \mathrm{~Hz}, 12-\mathrm{H})$. The above data are practically identical with those of methyl benthamate monoacetate (11b) reported in the literature. ${ }^{9)}$

F-II and F-III were each suspended in $\mathrm{CH}_{2} \mathrm{Cl}_{2}$ and the insoluble substances ( $450 \mathrm{mg}$ and $710 \mathrm{mg}$, respectively) were collected by filtration and methylated with $\mathrm{CH}_{2} \mathrm{~N}_{2}$ to give an additional crop of methyl ursolate. The filtrate from F-II was concentrated and the residue $(2.1 \mathrm{~g})$ was diluted with dil. $\mathrm{NaOH}(100 \mathrm{ml})$, then extracted with $\mathrm{CH}_{2} \mathrm{Cl}_{2}$ $(50 \mathrm{ml} \times 3)$. The $\mathrm{CH}_{2} \mathrm{Cl}_{2}$ layer was washed with water, dried, and concentrated to give a residue $(1.5 \mathrm{~g})$. This residue was roughly separated by silica gel $(80 \mathrm{~g})$ column chromatography and the fractions were further purified by repeated PLC using acetone- $\mathrm{CHCl}_{3}(5: 95)$ as the eluent to give oleanolic acid (13a) (130 $\left.\mathrm{mg}\right)$, 3-epiursolic acid (5a) (4.2 $\left.\mathrm{mg}\right)$, a mixture of ursonic acid (6a) and oleanonic acid (14a) $(3.9 \mathrm{mg}$ ), betulinic acid (18a) (13 mg), and betulin (19a) (2 mg). These compounds except for 5 a were methylated with $\mathrm{CH}_{2} \mathrm{~N}_{2}$ and identified by GC, MS, and ${ }^{1} \mathrm{H}-\mathrm{NMR}$ comparisons with corresponding authentic samples. Compound $5 \mathrm{a}(1.6 \mathrm{mg})$ was methylated with $\mathrm{CH}_{2} \mathrm{~N}_{2}$ and oxidized with $\mathrm{CrO}_{3}-$ $\mathrm{AcOH}$ at room temperature for $2 \mathrm{~h}$. The product was purified by $\mathrm{PLC}$ (developed with acetone- $\mathrm{CHCl}_{3}, 5: 95$ ) to give 6b $(1 \mathrm{mg})$, which was identified by GC and ${ }^{1} \mathrm{H}-\mathrm{NMR}$ comparison with an authentic sample.

F-IV was acetylated with $\mathrm{Ac}_{2} \mathrm{O}$-pyridine at room temperature for $4 \mathrm{~h}$ and the product was subjected to silica gel $(70 \mathrm{~g})$ column chromatography with AcOEt-hexane as the eluent. The AcOEt-hexane (2:8) eluate (178 $\mathrm{mg})$ was methylated with $\mathrm{CH}_{2} \mathrm{~N}_{2}$ and the product was subjected to PLC with $\mathrm{CHCl}_{3}$ to afford the following compounds.

1) Methyl $2 \alpha$-hydroxyursolate diacetate $(7 \mathbf{b})(18 \mathrm{mg})$, amorphous powder, $[\alpha]_{\mathrm{D}}^{22}+17^{\circ}\left(c=1.7, \mathrm{CHCl}_{3}\right)$. $\mathrm{MS}$ $m / z: 570\left(\mathbf{M}^{+}\right), 510,450,262,249,203,189,133$. High resolution MS: Found 570.3912, Calcd for $\mathrm{C}_{35} \mathrm{H}_{54} \mathrm{O}_{6}\left(\mathrm{M}^{+}\right)$ 570.3919. ${ }^{1} \mathrm{H}-\mathrm{NMR}\left(\mathrm{CDCl}_{3}\right) \delta: 0.74\left(3 \mathrm{H}, \mathrm{s}, 26-\mathrm{H}_{3}\right), 0.83-0.90\left(6 \mathrm{H}, 29-\right.$ and $\left.30-\mathrm{H}_{3}\right), 0.90\left(6 \mathrm{H}, \mathrm{s}, 23-\right.$ and $\left.24-\mathrm{H}_{3}\right), 1.05$ $\left(3 \mathrm{H}, \mathrm{s}, 25-\mathrm{H}_{3}\right), 1.07\left(3 \mathrm{H}, \mathrm{s}, 27-\mathrm{H}_{3}\right), 1.98$ and 2.07 (each $\left.3 \mathrm{H}, \mathrm{s}, \mathrm{OAc}\right), 2.25(1 \mathrm{H}, \mathrm{d}, J=11 \mathrm{~Hz}, 18-\mathrm{H}), 3.62(3 \mathrm{H}, \mathrm{s}$, $\left.\mathrm{COOCH}_{3}\right), 4.78(1 \mathrm{H}, \mathrm{d}, J=10 \mathrm{~Hz}, 3-\mathrm{H}), 5.14(1 \mathrm{H}, \mathrm{td}, J=10,4.5 \mathrm{~Hz}, 2-\mathrm{H})$, and $5.23(1 \mathrm{H}, \mathrm{m}, 12-\mathrm{H})$. These spectral data are compatible with those of $7 \mathbf{b}$ reported in the literature. $\left.{ }^{6}\right)$

2) A mixture of methyl 3 $\beta, 23$-diacetoxyurs-12-en-28-oate (1b) and methyl hederagenin diacetate (16b) $(12 \mathrm{mg}$, approximately $7: 3$ on GC analysis). Purification of this mixture by HPLC is described below.

3) Methyl 3 $\beta$,24-diacetoxyurs-12-en-28-oate (2b) ( $2 \mathrm{mg}$ ), colorless needles (from $\mathrm{MeOH}$ ), $\mathrm{mp} 180-182^{\circ} \mathrm{C}$, $[\alpha]_{\mathrm{D}}^{22}+50.8^{\circ}\left(c=0.12, \mathrm{CHCl}_{3}\right)$. MS $m / z: 570\left(\mathrm{M}^{+}\right), 510,450,262,249,203,189,133$. High resolution MS: Found 570.3882, Calcd for $\mathrm{C}_{35} \mathrm{H}_{54} \mathrm{O}_{6}\left(\mathrm{M}^{+}\right)$570.3919; Found 262.1922, Calcd for $\mathrm{C}_{17} \mathrm{H}_{26} \mathrm{O}_{2}$ (a) 262.1932; Found 249.1815, Calcd for $\mathrm{C}_{16} \mathrm{H}_{25} \mathrm{O}_{2}$ (b) 249.1854; Found 203.1790, Calcd for $\mathrm{C}_{15} \mathrm{H}_{23}$ (c) 203.1800; Found 189.1627, Calcd for $\mathrm{C}_{14} \mathrm{H}_{21}$ (c-14) 189.1642; Found 133.0991, Calcd for $\mathrm{C}_{10} \mathrm{H}_{13}$ (d) 133.1016. IR $v_{\max }^{\mathrm{KBr}} \mathrm{cm}^{-1}: 1730,1230 .{ }^{1} \mathrm{H}-\mathrm{NMR}\left(\mathrm{CDCl}_{3}\right) \delta$ : $0.74\left(3 \mathrm{H}, \mathrm{s}, 26-\mathrm{H}_{3}\right), 0.85$ and 0.94 (each $3 \mathrm{H}, \mathrm{d}, J=6 \mathrm{~Hz}, 29-$ and $\left.30-\mathrm{H}_{3}\right), 0.95\left(3 \mathrm{H}, \mathrm{s}, 23-\mathrm{H}_{3}\right), 1.01\left(3 \mathrm{H}, \mathrm{s}, 25-\mathrm{H}_{3}\right), 1.07$ $\left(3 \mathrm{H}, \mathrm{s}, 27-\mathrm{H}_{3}\right), 2.05$ and 2.07 (each $\left.3 \mathrm{H}, \mathrm{s}, \mathrm{OAc}\right), 2.25(1 \mathrm{H}, \mathrm{d}, J=11 \mathrm{~Hz}, 18-\mathrm{H}), 3.61\left(3 \mathrm{H}, \mathrm{s}, \mathrm{COOCH}_{3}\right), 4.13$ and 4.36 (each $\left.1 \mathrm{H}, \mathrm{d}, J=12 \mathrm{~Hz}, 24-\mathrm{H}_{2}\right), 4.60(1 \mathrm{H}, \mathrm{dd}, J=9,7 \mathrm{~Hz}, 3-\mathrm{H})$, and $5.26(1 \mathrm{H}, \mathrm{brt}, J=3.5 \mathrm{~Hz}, 12-\mathrm{H})$.

4) Methyl $2 \alpha$-hydroxy-3-epiursolate diacetate (9b) (3 mg), amorphous powder, $[\alpha]_{\mathrm{D}}^{22}+15^{\circ}\left(c=0.25, \mathrm{CHCl}_{3}\right)$. MS $m / z: 570\left(\mathrm{M}^{+}\right), 510,450,262,249,203,189,133$. High resolution MS: Found 570.3876, Calcd for $\mathrm{C}_{35} \mathrm{H}_{54} \mathrm{O}_{6}\left(\mathrm{M}^{+}\right)$ 570.3919. ${ }^{1} \mathrm{H}-\mathrm{NMR}\left(\mathrm{CDCl}_{3}\right) \delta: 0.75\left(3 \mathrm{H}, \mathrm{s}, 26-\mathrm{H}_{3}\right), 0.85$ and 0.93 (each $3 \mathrm{H}, \mathrm{d}, J=6 \mathrm{~Hz}, 29-$ and $\left.30-\mathrm{H}_{3}\right), 0.87(3 \mathrm{H}, \mathrm{s}$, $\left.23-\mathrm{H}_{3}\right), 0.98\left(3 \mathrm{H}, \mathrm{s}, 24-\mathrm{H}_{3}\right), 1.04\left(3 \mathrm{H}, \mathrm{s}, 25-\mathrm{H}_{3}\right), 1.11\left(3 \mathrm{H}, \mathrm{s}, 27-\mathrm{H}_{3}\right), 1.97$ and $2.12($ each $3 \mathrm{H}, \mathrm{s}, \mathrm{OAc}), 2.25(1 \mathrm{H}, \mathrm{d}, J=$ $11 \mathrm{~Hz}, 18-\mathrm{H}), 3.62\left(3 \mathrm{H}, \mathrm{s}, \mathrm{COOCH}_{3}\right), 4.99(1 \mathrm{H}, \mathrm{d}, J=2.5 \mathrm{~Hz}, 3-\mathrm{H})$, and $5.20-5.32(2 \mathrm{H}, \mathrm{m}, 2-$ and $12-\mathrm{H})$. These spectral data are compatible with the reported values. ${ }^{7)}$

5) Methyl euscaphate diacetate $(\mathbf{1 2 b})(4 \mathrm{mg})$, colorless needles, $\mathrm{mp} 115-118^{\circ} \mathrm{C},[\alpha]_{\mathrm{D}}^{22}+17^{\circ}\left(c=0.35, \mathrm{CHCl}_{3}\right)$. This compound was identified by direct comparison of the TLC behavior, ${ }^{1} \mathrm{H}-\mathrm{NMR}$, and GC with those of an authentic sample.

6) Methyl sumaresinolate monoacetate $(\mathbf{1 5 b})(4 \mathrm{mg})$, colorless needles (from EtOH), $\mathrm{mp} 220-222^{\circ} \mathrm{C}$. This was identified by GC and ${ }^{1} \mathrm{H}-\mathrm{NMR}$ comparisons with an authentic sample.

F-V $(1.0 \mathrm{~g})$ was also acetylated in the same manner as described above and the product was chromatographed on a silica gel $(50 \mathrm{~g})$ column. The eluate with $\mathrm{MeOH}-\mathrm{CHCl}_{3}(2: 98)(120 \mathrm{mg})$ was treated with $\mathrm{CH}_{2} \mathrm{~N}_{2}$ and the resulting methyl ester was separated by PLC with AcOEt-benzene $(2: 8)$ as the eluent. The least polar band afforded methyl $2 \alpha, 3 \alpha, 23$-triacetoxyurs-12-en-28-oate $(\mathbf{1 0 b})(10 \mathrm{mg})$, amorphous powder, $[\alpha]_{\mathrm{D}}^{22}+37^{\circ}\left(c=0.35, \mathrm{CHCl}_{3}\right) . \mathrm{MS} m / z: 628$ $\left(\mathrm{M}^{+}\right), 568,508,448,262,249,203,189,133$. High resolution MS: Found 628.4022, Calcd for $\mathrm{C}_{37} \mathrm{H}_{56} \mathrm{O}_{8} 628.3975 .{ }^{1} \mathrm{H}^{-}$ NMR $\left(\mathrm{CDCl}_{3}\right) \delta: 0.75\left(3 \mathrm{H}, \mathrm{s}, 26-\mathrm{H}_{3}\right), 0.85$ and 0.93 (each $3 \mathrm{H}, \mathrm{d}, J=6 \mathrm{~Hz}, 29-$ and $\left.30-\mathrm{H}_{3}\right), 1.07\left(3 \mathrm{H}, \mathrm{s}, 24-\mathrm{H}_{3}\right), 1.11$ $\left(6 \mathrm{H}, \mathrm{s}, 25-\right.$ and $\left.27-\mathrm{H}_{3}\right), 1.95,2.00$, and 2.06 (each $\left.3 \mathrm{H}, \mathrm{s}, \mathrm{OAc}\right), 2.25(1 \mathrm{H}, \mathrm{d}, J=11 \mathrm{~Hz}, 18-\mathrm{H}), 3.61\left(3 \mathrm{H}, \mathrm{s}, \mathrm{COOCH}_{3}\right)$, 3.73 and 4.11 (each $\left.1 \mathrm{H}, \mathrm{d}, J=12 \mathrm{~Hz}, 23-\mathrm{H}_{2}\right)$, and $5.18-5.37(3 \mathrm{H}, \mathrm{m}, 2-, 3-$, and $12-\mathrm{H}){ }^{8}{ }^{8}$ The middle band gave a mixture of methyl asiatate triacetate $(8 \mathrm{~b})$ and methyl arjunolate triacetate $(\mathbf{1 7 b})(40 \mathrm{mg})$ (approximate ratio of $62: 38$ by GC analysis). Both compounds were identified by GC and GC-MS comparisons with corresponding authentic samples. The most polar band gave impure methyl $2 \alpha, 3 \beta, 24$-triacetoxyurs-12-en-28-oate (3b) (6 mg), purification of which is described below.

Separation of the Mixture of Methyl 3ß,23-Triacetoxyurs-12-en-28-oate (1b) and Methyl Hederagenin Diacetate (16b) by HPLC — Preparative HPLC was performed on a Waters Associates ALC/GPC 201D compact type liquid chromatograph using a TSK-GEL ODS-120A column (column size, $4.6 \mathrm{~mm}$ i.d. $\times 25 \mathrm{~cm}$; detector setting, UV 
$215 \mathrm{~nm}$ ) with acetonitrile as the eluent (flow rate $0.5 \mathrm{ml} / \mathrm{min}$ ). The mixture (1b and 16b) $(12 \mathrm{mg})$ gave $16 \mathrm{~b}(1.0 \mathrm{mg})$ and 1b $(3.7 \mathrm{mg})$. The former was identified by GC, MS, and ${ }^{1} \mathrm{H}-\mathrm{NMR}$ comparisons with an authentic sample. Methyl $3 \beta, 23$-diacetoxyurs-12-en-28-oate $(\mathbf{1 b})$ was obtained as colorless needles (from EtOH), mp $180-181.5^{\circ} \mathrm{C}$, $[\alpha]_{\mathrm{D}}^{21}$ $+64.1^{\circ}\left(c=0.22, \mathrm{CHCl}_{3}\right)$. MS $m / z: 570\left(\mathrm{M}^{+}\right), 510,450,262,249,203,189,133$. High resolution MS: Found 570.3913, Calcd for $\mathrm{C}_{35} \mathrm{H}_{54} \mathrm{O}_{6}\left(\mathrm{M}^{+}\right)$570.3919; Found 262.1937, Calcd for $\mathrm{C}_{17} \mathrm{H}_{26} \mathrm{O}_{2}$ (a) 262.1933; Found 249.1842, Calcd for $\mathrm{C}_{16} \mathrm{H}_{25} \mathrm{O}_{2}$ (b) 249.1854; Found 203.1789, Calcd for $\mathrm{C}_{15} \mathrm{H}_{23}$ (c) 203.1799. IR $v_{\max }^{\mathrm{KBr}} \mathrm{cm}^{-1}: 1730,1230 .{ }^{1} \mathrm{H}$ NMR $\left(\mathrm{CDCl}_{3}\right) \delta: 0.75\left(3 \mathrm{H}, \mathrm{s}, 26-\mathrm{H}_{3}\right), 0.83\left(3 \mathrm{H}, \mathrm{s}, 24-\mathrm{H}_{3}\right), 0.87$ and 0.94 (each $3 \mathrm{H}, \mathrm{d}, J=6 \mathrm{~Hz}, 29-$ and $\left.30-\mathrm{H}_{3}\right), 0.98$ $\left(3 \mathrm{H}, \mathrm{s}, 25-\mathrm{H}_{3}\right), 1.07\left(3 \mathrm{H}, \mathrm{s}, 27-\mathrm{H}_{3}\right), 2.02$ and 2.07 (each $\left.3 \mathrm{H}, \mathrm{s}, \mathrm{OAc}\right), 2.25(1 \mathrm{H}, \mathrm{d}, J=11 \mathrm{~Hz}, 18-\mathrm{H}), 3.62(3 \mathrm{H}, \mathrm{s}$, $\left.\mathrm{COOCH}_{3}\right), 3.71$ and $3.88\left(\right.$ each $\left.1 \mathrm{H}, \mathrm{d}, J=12 \mathrm{~Hz}, 23-\mathrm{H}_{2}\right), 4.81(1 \mathrm{H}, \mathrm{dd}, J=10,5.5 \mathrm{~Hz}, 3-\mathrm{H})$, and $5.23(1 \mathrm{H}$, br t, $J=$ $3.5 \mathrm{~Hz}, 12-\mathrm{H})$.

Purification of Methyl 2 $\alpha, 3 \beta, 24$-Triacetoxyurs-12-en-28-oate (3b) by HPLC-Preparative HPLC of the abovementioned impure $\mathbf{3 b}$ under the same conditions as used for $\mathbf{1 b}$, gave a pure sample (3b) (1.4 mg), amorphous powder, $[\alpha]_{\mathrm{D}}^{21}+51^{\varsigma}\left(c=0.1, \mathrm{CHCl}_{3}\right)$. MS $m / z: 628\left(\mathrm{M}^{+}\right), 568,508,262,249,203,189,133$. High resolution MS: Found 628.3954, Calcd for $\mathrm{C}_{37} \mathrm{H}_{56} \mathrm{O}_{8}\left(\mathrm{M}^{+}\right)$628.3974; Found 262.1918, Calcd for $\mathrm{C}_{17} \mathrm{H}_{26} \mathrm{O}_{2}$ (a) 262.1932; Found 249.1820, Calcd for $\mathrm{C}_{16} \mathrm{H}_{25} \mathrm{O}_{2}$ (b) 249.1854; Found 203.1785, Calcd for $\mathrm{C}_{15} \mathrm{H}_{23}$ (c) 203.1799; Found 189.1629, Calcd for $\mathrm{C}_{14} \mathrm{H}_{21}$ (c-14) 189.1642; Found 133.1000, Calcd for $\mathrm{C}_{10} \mathrm{H}_{13}$ (d) 133.1016. IR $v_{\max }^{\mathrm{KBr}} \mathrm{cm}^{-1}: 1740,1235$. ${ }^{1} \mathrm{H}-\mathrm{NMR}$ $\left(\mathrm{CDCl}_{3}\right) \delta: 0.73\left(3 \mathrm{H}, \mathrm{s}, 26-\mathrm{H}_{3}\right), 0.83$ and $0.94\left(\right.$ each $3 \mathrm{H}, \mathrm{d}, J=6 \mathrm{~Hz}, 29-$ and $\left.30-\mathrm{H}_{3}\right), 1.02\left(3 \mathrm{H}, \mathrm{s}, 23-\mathrm{H}_{3}\right), 1.06(3 \mathrm{H}, \mathrm{s}$, $\left.25-\mathrm{H}_{3}\right), 1.07\left(3 \mathrm{H}, \mathrm{s}, 27-\mathrm{H}_{3}\right), 1.97,2.05$, and 2.06 (each $\left.3 \mathrm{H}, \mathrm{s}, \mathrm{OAc}\right), 2.25(1 \mathrm{H}, \mathrm{d}, J=11 \mathrm{~Hz}, 18-\mathrm{H}), 3.60(3 \mathrm{H}, \mathrm{s}$, $\left.\mathrm{COOCH}_{3}\right), 4.20\left(2 \mathrm{H}, \mathrm{s}, 24-\mathrm{H}_{2}\right), 4.86(1 \mathrm{H}, \mathrm{d}, J=10.5 \mathrm{~Hz}, 3-\mathrm{H}), 5.18(1 \mathrm{H}, \mathrm{td}, J=10.5,4.5 \mathrm{~Hz}, 2-\mathrm{H})$, and $5.25(1 \mathrm{H}$, br t, $J=3.5 \mathrm{~Hz}, 12-\mathrm{H})$.

Acknowledgement We are grateful to Dr. T. Kawasaki of Kyushu University for the gift of the sample of arjunolic acid, to Dr. I. Kitagawa of Osaka University for the samples of ursolic acid and betulin, to Dr. H. Hikino of Tohoku University for the sample of sumaresinolic acid, to Dr. J. Sakakibara of Nagoya City University for the samples of $2 \alpha, 3 \alpha, 24$-trihydroxyurs-12-en-28-oic acid and asiatic acid, and to Dr. M. Takani of Kanazawa University for the samples of barbinervic acid and euscaphic acid.

\section{References and Notes}

1) R. N. Chopra, J. C. Chopra, K. L. Handa, and L. D. Kapur, "Chopra's Indigenous Drugs of India," 2nd ed., U. N. Dhur \& Sons Private Ltd., Calcutta, 1958, p. 339.

2) K. S. Mukherjee, M. K. Bhattacharya, and P. K. Ghosh, Phytochemistry, 21, 2416 (1982).

3) H. T. Cheung and M. C. Feng, J. Chem. Soc., (C), 1968, 1047.

4) K. Takahashi, S. Kawaguchi, K. Nishimura, K. Kubota, Y. Tanabe, and M. Takani, Chem. Pharm. Bull., 22, 650 (1974).

5) C. Djerassi, G. H. Thomas, and O. Jeger, Helv. Chim. Acta, 38, 1304 (1955).

6) A. T. Glen, W. Lawrie, J. McLean, and M. EI-Garby Younes, J. Chem. Soc., (C), 1967, 510; W. M. Bandaranayake, S. P. Gunasekera, S. Karunanayake, S. Sotheeswaran, and M. U. S. Sultanbawa, Phytochemistry, 14, 2043 (1975).

7) H. W. A. Biessels, A. C. van der Kerk-van Hoof, J. J. Kettenes-van der Bosch, and C. A. Salemink, Phytochemistry, 13, 203 (1974).

8) R. Tandon, G. K. Jain, R. Pal, and N. M. Khanna, Indian J. Chem., 19B, 819 (1980). The ${ }^{1}$ H-NMR spectrum of 10b was not consistent with that reported in this paper, but was very similar to that of methyl $2 \alpha, 3 \alpha, 19,23-$ tetrahydroxyurs-12-en-28-oate triacetate. See C. H. Brieskorn and W. Riedel, Arch. Pharm., 310, 910 (1977).

9) J. Bermejo, J. L. Bretón, and G. de la Fuente y A. G. González, Tetrahedron Lett., 1967, 4649.

10) H. Budzikiewicz, J. M. Wilson, and C. Djerassi, J. Am. Chem. Soc., 85, 3688 (1963).

11) a) H. T. Cheung and D. G. Williamson, Tetrahedron, 25, 119 (1969); b) H. T. Cheung and T. C. Yan, Aust. J. Chem., 25, 2003 (1972).

12) J. Sakakibara and T. Kaiya, Phytochemistry, 22, 2547 (1983).

13) M. Takani, K. Kubota, K. Nozawa, T. Ushiki, and K. Takahashi, Chem. Pharm. Bull., 25, 981 (1977). 